\title{
PENGEMBANGAN PROFESIONALISME GURU MELALUI PELATIHAN PENYUSUNAN KARYA TULIS ILMIAH DI WILAYAH PEDALAMAN
}

\author{
Muhsinah Annisa, Hariyati Hamid, Kartini \\ Universitas Borneo Tarakan \\ Email: echa.ok@gmail.com
}

\begin{abstract}
Abstrak
Kecamatan Long Pujungan Kabupaten Malinau merupakan salah satu daerah di provinsi Kalimatan Utara (Kaltara) yang termasuk wilayah pedalaman. Malinau berbatasan langsung dengan negara tetangga, yaitu Sabah, Malaysia Timur. Sebagai daerah yang berbatasan langsung dengan negara lain. Guru profesional harus memiliki 4 kompetensi, salah satunya yaitu kompetensi profesional. Berdasarkan wawancara dengan guru-guru di SDN 001 Long Pujungan, ditemukan permasalah yaitu banyak guru yang mengalami kendalal dalam kenaikan pangkat, salah satunya dikarenakan minimnya publikasi karya ilmiah. Hal ini disebabkan oleh pemahaman guru belum memadai dalam penyusunan karya tulis ilmiah. Pelatihan Pengabdian Masyarakat menggunakan metode yang digunakan adalah ceramah, penugasan dan diskusi serta pendampingan pembuatan karya tulis ilmiah dan perangkat pembelajaran. Langkah-langkah kegiatan yaitu dengan pelatihan berupa teori, penugasan secara mandiri dan diskusi. Sasaran kegiatan ini adalah guru-guru sekolah dasar di Kecamatan Long Pujungan Kabupaten Malinau. Data angket yang diberikan kepada peserta menunjukkan bahwa 100\% merupakan hal yang baru, $84 \%$ pelatihan ini sangat membantu dalam pelaksanaan, $88 \%$ peserta memperoleh tambahan pengetahuan dan keterampilan, $12 \%$ masih tidak mengerti. $96 \%$ peserta menjawab bahwa guru memerlukan referensi dalam pelaksanaan tugas, Dalam ketersediaan referensi, $92 \%$ menyatakan bahwa referensi ada di tempat mereka bekerja, tapi belum mencukupi. $100 \%$ peserta menyatakan bahwa petihan sangat efektf. dan $100 \%$ menyatakan perlu ada pelatihan lanjutan.
\end{abstract}

Kata Kunci: Penyusunan Karya Tulis IImiah, Guru Sekolah Dasar, Daerah Pedalaman

\begin{abstract}
Pujungan Malinau sub-district is one of the areas in the province of North Kalimantan (Kaltara) which includes rural areas. Malinau directly borders with neighboring states, namely Sabah, East Malaysia. As a region which directly borders with other countries. Professional teachers should have 4 competence, one of which is pedagogical, one of the competencies that need to be owned by a teacher is the ability to compile learning assessment instrument. As mentioned in Permendikbud No. 66 of 2013 that the assessments made should be based on the assessment of reference for educators, educational and governmental units in primary and secondary education units. Based on interviews with teachers at SDN 001 Pujungan, found problems that a lot of teachers who have kendalal in the promotion, one of them due to lack of publication of scientific papers. This is due to inadequate understanding of teachers in the preparation of scientific papers. Community Service training methods used are lectures, assignments and discussions as well as assisting the manufacture of scientific papers and learning devices. Step-by-step activities, namely with a theoretical training, assignments independently and discussions. Goal of this activity is the primary school teachers in the district Pujungan Malinau District. Data questionnaire given to participants showed that $100 \%$ is a new thing, $84 \%$ of this training is very helpful in implementation, $88 \%$ of participants acquire additional knowledge and skills, $12 \%$ still do not understand. $96 \%$ of participants responded that teachers need a reference in the implementation of the tasks, in the availability of reference, $92 \%$ stated that the reference in which they work, but not sufficient. $100 \%$ of participants stated that petihan very efektf. and $100 \%$ expressed need further training.
\end{abstract}

Keywords: writing scientific papers, Elementary School Teacher, Rural Areas 


\section{PENDAHULUAN}

\section{Analisis Situasi}

$$
\text { Kalimantan Utara (Kaltara) }
$$

merupakan termuda Indonesia, resmi disahkan menjadi provinsi dalam rapat paripurna DPR pada tanggal 25 Oktober 2012 berdasarkan Undang-undang Nomor 20 Tahun 2012. Kalimantan Utara berbatasan langsung dengan negara tetangga, yaitu Negara Bagian Sabah dan Serawak, Malaysia Timur. Sebagai provinsi baru yang berbatasan langsung dengan negara lain, Kaltara mempunyai peranan yang sangat penting dalam menjaga eksistensi negara Indonesia. Salah satu bagian penting dalam pembangunan SDM adalah bidang pendidikan. Hal ini senada dengan pembukaan UUD 1945 mengamanatkan bahwa pembentukan pemerintahan negara indonesia yaitu salah satunya adalah untuk mencerdaskan kehidupan bangsa, untuk mewujudkannya maka diatur dalam UUD 1945 Pasal 31 ayat 3 yang menyatakan bahwa pemerintahan mengusahakan dan menyelenggarakan satu sistem pendidikan nasional, yang meningkatkan keimanan dan ketakwaan serta akhlak mulia dalam rangka mencerdaskan kehidupan bangsa, yang diatur dalam undang-undang.

Salah satu bagian yang sangat berperan dalam mencerdaskan kehidupan bangsa adalah guru. Sesuai dengan Permendiknas No. 16 Tahun 2007 menyebutkan bahwa standar kualifikasi akademik dan standar kompetensi guru diuraikan bahwa standar kompetensi guru terdiri dari kompetensi pedagogik, kepribadian, social dan professional. Salah satu bagian dari kompetensi guru dalam bidang profesional adalah bagaimana guru dapat menghasilkan dan mempublikasikan karya ilmiah. Bagian unsur dan sub unsur kegiatan Guru yang dinilai angka kreditnya adalah Pengembangan keprofesian berkelanjutan, yaitu publikasi ilmiah atas hasil penelitian atau gagasan inovatif pada bidang pendidikan formal. Kewajiban tersebut berlaku sejak 1 Januari 2013 dan merujuk Peraturan Menteri Negara Pendayagunaan Aparatur Negara (PermenPAN) Nomor 16 Tahun 2009 tentang Jabatan Fungsional Guru yang ingin naik jenjang menjadi golongan III b ke atas. Aturan ini berbeda dengan ketentuan sebelumnya, yakni PermenPAN Nomor 84 Tahun 1993 tentang Jabatan Fungsional Guru dan Angka Kredit. Aturan lama mewajibkan guru pada jenjang IV a harus membuat karya tulis ilmiah.

Berdasarkan wawancara dengan guru-guru di SDN 001 Long Pujungan, ditemukan permasalah yang terkait dengan pembuatan karya tulis ilmiah, guru belum bisa membuat karya ilmiah dan belum pernah mempublikasikan karya ilmiah tersebut, sehingga para guru terganjal dalam hal kenaikan pangkat ke pangkat yang lebih tinggi. Selain mengalami kesulitan danlam meyusun karya ilmiah, guru masih kurang memahami dalam membuat perangkat pembelajaran. Perangkat pembelajaran tentunya berkaitan dengan karya ilmiah yang akan dilakukan guru, dalam hal ini penelitian tindakan keals (PTK).

Berdasarkan beberapa fakta di atas yang merupakan sebagian kecil dari permasalahan-permasalahan yang terjadi di bidang pendidikan, maka pengusul bersama dengan guru SDN menimbang perlu dilaksanakan kegiatan pelatihan guru dalam bentuk Ipteks Bagi Masyarakat ( $\left.\mathrm{l}_{b} \mathrm{M}\right)$ di Kabupaten Malinau dalam kegiatan pelatihan penulisan karya ilmiah.

\section{METODE PELAKSANAAN}

Kegiatan ini diadakan tanggal 5 Oktober 2016. Adapun prosedur pelaksanaan yang akan digunakan adalah sebagai berikut. yang akan digunakan adalah sebagai berikut:

\section{Metode Pelaksanaan Program}

Langkah-langkah pelaksanaan kegiatan adalah sebagai berikut:

1. Sebelum berangkat ke lokasi mitra, pengusul menghubungi kepala sekolah SDN 001 Malinau Barat untuk meminta kesiapan pelaksanaan kegiatan pelatihan di sekolah mereka.

2. Dosen pelaksana mempersiapkan materi penyusunan karya ilmiah

3. Pelatihan penyusunan penyusunan dilakukan dengan metode ceramah, diskusi, tanya jawab dan pendampingan kelompok yang 
dibagikan berdasarkan mata pelajaran di seklah.

\section{HASIL DAN PEMBAHASAN}

Kegiatan pelatihan ini didahului dengan wawancara dengan guru dan kepala sekolah SDN 001 Long Pujungan, didapat permasalahan yaitu guru belum pernah menyusun karya tulis ilmiah dan kesuliatn dalam membuat perangkat pembelajaran. Metode yang dilakukan dalam pelatihan ini yaitu dengan ceramah, diskusi dan pendampingan penyusunan. Dalam kegiatan pelatihan, diawali dengan brain storming tentang bagaimana cara guru dalam dalam menyusun karya ilmiah dan membuat perangkat pembelajaran. Ternyata selama ini guru belum pernah menyusun karya ilmiah dan dalam pembuatan perangkat pembelajaran, guru cenderung copy paste perangkat yang sudah ada tanpa memperbaikinya.

Berdasarkan kondisi tersebut, maka dalam pelatihan ini dilakukan dengan metode ceramah untuk memperdalam pemahaman tentang karya tulis ilmiah, dalam hal ini karya ilmiah yang diajarkan kepada guru adalah penelitian tindakan kelas. Selain mengajarkan penelitian tindakan kelas, guru juga diajarkan bagaimana membuat perangkat pembelajaran yang baik. Karena penelitian tindakan kelas dan perangkat pembelajaran merupakan suatu kesatuan utuh yang tidak dapat dipisahkan. Dalam kegiatan pelatihan, peserta dikelompokkan berdasarkan mapel dan peserta mempraktekkan menyusun karya ilmiah. Kegiatan pelatihan penyusuan karya ilmiah disajikan pada gambar 1 berikut.

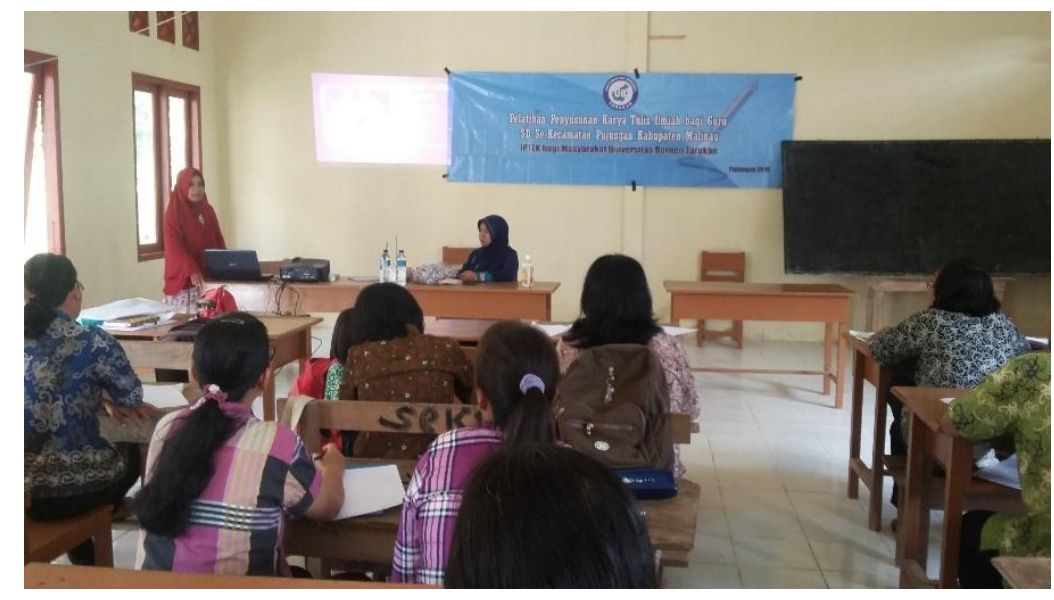

Gambar 1. Penyampaian Materi Penyusunan Karya IImiah

Setelah pelatihan peserta diberikan
data umpan balik. Data angket menunjukkan bahwa 58,3\% merupakan hal yang baru, $75 \%$ pelatihan ini sangat membantu dalam pelaksanaan tugas dan 25\% mengatakan cukup membantu dalam pelaksanaan tugas, sebanyak $100 \%$ peserta memperoleh tambahan pengetahuan dan keterampilan dan pelatihan sangat efektif. 91,3\% mengatakan waktu seimbang dengan materi dan tugas dan 8,35 mengatakan cukup seimbang antara materi dan tugas, dan $100 \%$ menyatakan perlu ada pelatihan lanjutan. Selain umpan balik terhadap pelatihan penyusunan soal, umpan balik juga dilakukan terhadap pembuatan perangkat pembelajaran, $90 \%$ guru antusias dalam membuat Rencana pelaksana pembelajaran (RPP), akan tetapi mereka masih kebingungan dalam membuat RPP yang baik, karena lokasi mereka sulit dijangkau yang membuat para guru jarang mendapatkan kesempatan dalam mengikuti pelatihan pengembangan diri, khususnya RPP dan perangkat pembelajran yang lain. Sumber belajar yang beraneka ragam juga kesulitan ditemui guru, mengingat daerah mereka merupakan daerah yang minim sumber listrik, sumber listrk masyarakat masih mengandalkan tenaga air dari sungai yang dikelola mandiri oleh masyarakat sekitar.

Berdasarkan wawancara yang dilakukan terhadap peserta pelatihan, mereka sangat antusias terhadap kegiatan 
